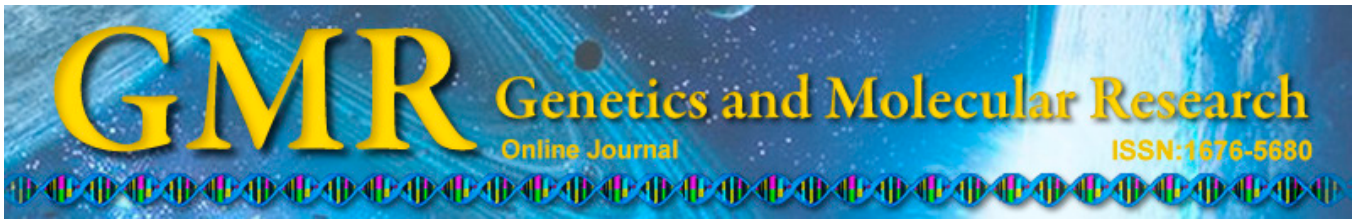

\title{
Evolution of rbcL among Lathyrus and Kupicha's classification
}

\author{
S. Marghali, N. Zitouna, M. Gharbi, I. Fadhlaoui and N. Trifi-Farah \\ Laboratory of Molecular Genetics, Immunology, and Biotechnology, \\ Faculty of Sciences, University of Tunis El Manar, Campus Universitaire, \\ El Manar, Tunis, Tunisia
}

Corresponding author: N. Trifi-Farah

E-mail: neila.trifi@fst.rnu.tn

Genet. Mol. Res. 13 (4): 8729-8739 (2014)

Received September 30, 2013

Accepted July 16, 2014

Published October 27, 2014

DOI http://dx.doi.org/10.4238/2014.October.27.14

\begin{abstract}
Phylogenetic relationships in the Lathyrus genus were examined using cpDNA data, particularly data attributed to the "barcode" $r b c L$ gene to construct a possible evolutionary scenario. Plant barcoding can be used to differentiate between species within a genus and to conserve DNA within the same species. We assessed the phylogeny of 29 species of Lathyrus using maximum parsimony, maximum likelihood and unweighted pair-group method and arithmetic mean. The classifications did not agree with current morphological and basic Lathyrus classification. Lathyrus belinensis is a new species that was not described by Kupicha; according to rbcL analysis, the species belongs in the Lathyrus genus. Additionally, the genus Lathyrus has undergone a rapid population expansion as indicated by neutral selection indices.
\end{abstract}

Key words: Plastid DNA; rbcL evolution; Nucleotide variations; Lathyrus; Phylogeny; rbcL 


\section{INTRODUCTION}

The genus Lathyrus (Fabaceae), a member of the tribe Vicieae, includes nearly 160 species of annual and perennial, autogamous, and allogamous herbaceous creeping plants, which are present throughout the temperate regions of the Northern hemisphere and South America. The main centers of diversity include the Mediterranean region, Asia Minor, and North America, as well as temperate South America and East Africa (Simola, 1986; Klamt and Schifino-Wittmann, 2000). Two periods have been proposed to explain the colonization of the Americas by this genus: during the Tertiary period, when Africa and South America were still united (Simola, 1986), or between the Cretaceous and Paleocene periods, through Greenland and Alaska (Kupicha, 1983). In South America, Lathyrus species have been found from Colombia to Tierra del Fuego, which likely migrated to the austral part of the continent through the Andean road (Burkart, 1935). All species have $2 n=2 x=14$ chromosomes, with a basic number of $\mathrm{n}=\mathrm{x}=7$ (Battistin et al., 1999).

Classification of the Lathyrus genus has been carried out in numerous studies. Most studies separate Lathyrus into 12 or 13 sections worldwide (Kupicha, 1983; Asmussen and Liston, 1998; ILDIS, 2002; Leht, 2009). Subsequent studies were based on the classification of Kupicha and focused on taxonomic groupings or were regionally limited. All of these classifications were based on morphological characters such as flower color, pod appearance, and size and color of the seeds.

In addition to morphological data, other complex traits have been used to study the infra-structure and evolution of generic species of Lathyrus using methods such as enzyme electrophoresis (Chowdhury and Slinkard, 2000; Chtourou-Ghorbel et al., 2001; Ben Brahim et al., 2002), chloroplast DNA restriction site analysis (Asmussen and Liston, 1998), and molecular markers [random amplified polymorphic DNA (RAPD), restriction fragment length polymorphism (RFLP), and inter-simple sequence repeat (ISSR)] (Croft et al., 1999; ChtourouGhorbel et al., 2002a,b; Belaïd et al., 2006). However, uncertainty still exists regarding the intuitive species relationships among members of the Lathyrus genus. Therefore, additional extensive analysis of these species is needed.

Recently, macromolecular characteristics such as nucleotide sequences of DNA or amino acid sequences of proteins have been used to reconstruct phylogenetic relationships of various organisms. The plastid gene ribulose-1,5-bisphosphate carboxylase/oxygenase (rbcL) has been shown to be useful for addressing phylogenetic relationships at a variety of taxonomic levels and within a number of taxonomic groups. Studies among the genera and species of Cypripedioideae by Albert (1994) and Dendrobiinae by Yukawa and Uehara (1996) indicated that the amount of sequence divergence exhibited by rbcL is sufficient and appropriate for addressing such relationships. Nucleotide sequences of the large subunit of rbcL were used for perform phylogenetic analyses, including in a wide range of angiosperms (Bremer et al., 1995; Olmstead and Reeves, 1995).

The purpose of the present study was to improve the phylogeny of the Lathyrus genus by including Lathyrus species and related known genera such as Vicia and Pisum to analyze whether the phylogeny inferred from rbcL nucleotide sequence data is correlated with that of Kupicha (1983). In this study, we examined the following points: 1) whether rbcL is an efficient tool for discriminating between close species, 2) the congruence with Kupicha classification, which was based on morphology, and 3) the evolution on the genus using neutral selection indices. 


\section{MATERIAL AND METHODS}

The analysis was carried out using 6 species of the Lathyrus genus (L. sativus, L. cicera, L. ochrus, L. sylvestris, L. tuberosus, and L. aphaca).

DNA was isolated from young and fresh leaves using the method described by Dellaporta et al. (1983). DNA was quantified by $0.8 \%$ agarose gel electrophoresis, which included uncut lambda DNA of known concentration. The DNA was diluted for further analyses.

\section{Laboratory procedures}

Polymerase chain reaction (PCR) amplification was carried out according to the following conditions: the $25-\mu \mathrm{L}$ reaction mixture contained 25 ng genomic DNA, 60 pg primers $(1 \mu \mathrm{L}), 100 \mu \mathrm{M}$ of each dNTP, $2.5 \mu \mathrm{L}$ 10X Taq DNA polymerase buffer, and 2 U Taq DNA polymerase (Invitrogen, Carlsbad, CA, USA). The sequences of the primers used in this study were (F) 5'-ATGTCACCACAAACAGAGACTAAAGC-3' (Levin et al., 2003) and (R) 5'-GTAAAATCAAGTCCACCRCG-3' (Kress and Erickson, 2007). PCRs were performed using a Perkin Elmer thermocycler (Waltham, MA, USA) as follows: an initiation step of 4 min at $95^{\circ} \mathrm{C}$, followed by 5 cycles for $30 \mathrm{~s}$ at $94^{\circ} \mathrm{C}$ for denaturation, $60 \mathrm{~s}$ at $55^{\circ} \mathrm{C}$ for hybridization, and $60 \mathrm{~s}$ at $72^{\circ} \mathrm{C}$ for elongation. These cycles were followed by 30 additional cycles at $30 \mathrm{~s}$ at $94^{\circ} \mathrm{C}$ for denaturation, $60 \mathrm{~s}$ at $54^{\circ} \mathrm{C}$ for hybridization, and $60 \mathrm{~s}$ at $72^{\circ} \mathrm{C}$. A final 1-min step at $72^{\circ} \mathrm{C}$ was included for final elongation.

Products were separated by electrophoresis on a $1.5 \%$ agarose gel in $0.5 \mathrm{X}$ Tris-Borate EDTA buffer, $\mathrm{pH} 8.3$, stained with ethidium bromide, and visualized under UV light. The size of amplified fragments was estimated by comparison to a 100-bp ladder that had been loaded simultaneously with the amplified DNA. The purified PCR products for the coding rbcL region were sequenced in both strands and the same primers were used for the sequencing step, carried out using the Big Dye Terminator Ready Reaction Kit on an ABI Prism ${ }^{\mathrm{TM}} 3130$ DNA Genetic Analyzer (Applied Biosystems, Hi-Tech Detection Systems, Tunis, Tunisia).

\section{Data analysis}

Each Lathyrus species was sequenced at least 5 times. Obtained sequences were first evaluated using the BLAST function in the NCBI database to ensure that the sequence was correct. Pics were then verified, and Taq errors were corrected to enhance the credibility of the results.

All sequences were submitted and published to the GenBank database NCBI (http:// www.ncbi.nlm.nih.gov/), but only 1 sequence was subsequently used to represent the corresponding species.

In the current study, other sequences were retrieved from NCBI and combined with the dataset for the evolutionary study of Lathyrus genus. Three Vicia and one Pisum sequences were included as out-groups. All sequences used in this study and their accession numbers are shown in Table 1.

Multiple alignment was accomplished using ClustalW, implemented using the Mega5 software (Tamura et al., 2011). The non-aligned regions (corresponding to the primer sequences) were excluded. The used primers in this study amplified only the barcoding frame of the $r b c L$ gene. Available and used sequences corresponded, in some cases, to the entire $r b c L$ gene. 
The composition and the characteristics of the $r b c L$ nucleotide sequences from the analyzed Lathyrus genus were determined using the Seaview4 software (Gouy et al., 2010).

Maximum likelihood, maximum parsimony (MP), and unweighted pair-group method and arithmetic mean (UPGMA) were used to assess phylogeny in the genus. All analyses were performed using the Mega5 software (Tamura et al., 2011) and the bootstrap consensus trees inferred from 1000 replicates were used to represent the evolutionary history of the taxa analyzed (Felsenstein, 1985). MP analysis was accompanied by measuring the consistency index (CI) and retention index (RI). In fact, CI and RI both measure the degree of "tree-likeness" in data under a parsimony model for character changes.

The DnaSP software (Rozas, 2009) was used to analyze the sequence contents: polymorphism, conservation, segregating sites, and nucleotide and haplotype diversities. This statistical tool analyzed the evolution of Lathyrus by computing the indices of Tajima's D, Fu and $\mathrm{Li} \mathrm{D}, \mathrm{Fu}$, and $\mathrm{Li} \mathrm{F}$ and determined the mismatch distribution of the pairwise difference.

\section{RESULTS AND DISCUSSION}

DNA sequence analysis is a fundamental method for studying the evolution of DNA coding and non-coding regions. In our study, the rbcL-coding frame was sequenced to determine the evolution and phylogeny of Lathyrus species in the Fabaceae family.

\section{rbcL data set}

Sequences in the current set were analyzed using the BLAST function on the NCBI database website. BLAST, which was used to verify the sequence identity, provides valuable insight into the efficiency of $r b c L$ short-sequence regions and acts as a barcode (Chase et al., 2005). Complete overlapping sequences for the barcode region of the $r b c L$ gene (between 1-599 bp) were successfully obtained for all accessions studied using the reverse primer designed by Kress and Erickson (2007). These nucleotide sequences were submitted to GenBank and published under the accession numbers listed in Table 1 . Total lengths of the newly sequenced regions (from our basic dataset) of L. tuberosus, L. sativus, L. cicera, L. sylvestris, $L$. aphaca, and L. ochrus were between 551-563 bp (L. ochrus and L. cicera, respectively). This length has been obtained for many plants using modified primers for barcoding analysis. In fact, Kress and Erickson (2007) found a mean size of $530 \mathrm{bp}$ for the rbcL frame.

The nucleotide composition was as follows: $27.6 \% \mathrm{~A}, 20.2 \% \mathrm{C}, 22.2 \% \mathrm{G}$, and $29.9 \%$ T. This composition agrees with results of Sulaiman et al. (2003), who examined 23 species from 16 genera of Mimoseae. A notable feature of the plastid genome is the high AT-content, both in coding regions and in non-coding regions (Howe et al., 2003).

Including the entire dataset (sequenced and retrieved from NCBI), 561 aligned characters, including gaps (488 sites without gaps), were used for phylogenetic analyses. Four hundred and forty-two constant characters $(90.6 \%)$ and 46 variable characters $(9.4 \%)$ were identified.

Among the constant characters, 3 long conserved regions were observed. The first was between 47 and 90 bp (5'-AAAACCAAAGATACTGATATCTTGGCAGCATTCCGAGTAA CTCC-3'), the second was located on the 276-316-bp frame (5'-ACCTTTTTGAAGAAGGT TCTGTTACTAACATGTTTACCTCC-3'), and the third frame (5'-AGAGATAAATTGAACA AGTATGGACGTCCC-3') was 434-463 bp. 
Table 1. Summary of Lathyrus species included in this study and GenBank accession numbers of rbcL coding sequence.

\begin{tabular}{|c|c|c|}
\hline Species & Accession Nos. & Reference \\
\hline Lathyrus sativus & Kc526196.1 & NCBI GenBank \\
\hline Lathyrus aphaca & Kc526159.1 & \\
\hline Lathyrus cicera & Kc526170.1 & \\
\hline Lathyrus ochrus & Kc526177.1 & \\
\hline Lathyrus sylvestris & Kc526183.1 & \\
\hline Lathyrus tuberosus & Kc526191.1 & \\
\hline Lathyrus angulatus & Jn661180.1 & \\
\hline Lathyrus davidii & Gq436352.1 & \\
\hline Lathyrus linifolius & Jn892522.1 & \\
\hline Lathyrus palustris & Jn891868.1 & \\
\hline Lathyrus nissolia & Jn892530.1 & \\
\hline Lathyrus bauhinii & $\mathrm{J}_{\mathrm{X} 505475.1}$ & \\
\hline Lathyrus hierosolymitanus & Jx505477.1 & \\
\hline Lathyrus inconspicuus & Jx505479.1 & \\
\hline Lathyrus pubescens & Jx505483.1 & \\
\hline Lathyrus belinensis & Jx505476.1 & \\
\hline Lathyrus venosus & Jx505484.1 & \\
\hline Lathyrus tingitanus & Hm850109.1 & \\
\hline Lathyrus niger & He963532.1 & \\
\hline Lathyrus sphaericus & Jn661186.1 & \\
\hline Lathyrus pratensis & Jn661186.1 & \\
\hline Lathyrus japonicus subsp. maritimus & Hm850107.1 & \\
\hline $\begin{array}{l}\text { Lathyrus clymenum } \\
\text {. }\end{array}$ & $\mathrm{Hm} 850105.1$ & \\
\hline Lathyrus hirsutus & Hm850106.1 & \\
\hline Lathyrus nervosus & $\mathrm{Jx} 505482.1$ & \\
\hline Vicia faba & Jn661200.1 & \\
\hline Vicia sativa & Hm850461.1 & \\
\hline Vicia villosa & $\mathrm{Hm} 850464.1$ & \\
\hline Pisum sativum subsp. sativum & Jn661190.1 & \\
\hline
\end{tabular}

Of the 46 segregating sites, 29 (63.04\%) were parsimony non-informative, while 17 $(36.95 \%)$ were parsimony informative. A sliding window represents the evolution of the segregating sites among the 561 characters analyzed (Figure 1A). The maximum number of segregating sites was 12 . The frame behind the $200 \mathrm{bp}$ was the maximum segregating region, which corresponded to the 379 nucleotide. However, the region upstream and downstream of $300 \mathrm{bp}$ was less parsimonious. These results were consistent with the conserved character of the $r b c L$ gene. Among plastid regions, this gene represented the best-characterized frame in species discrimination (CBOL Plant Working Group, 2009).
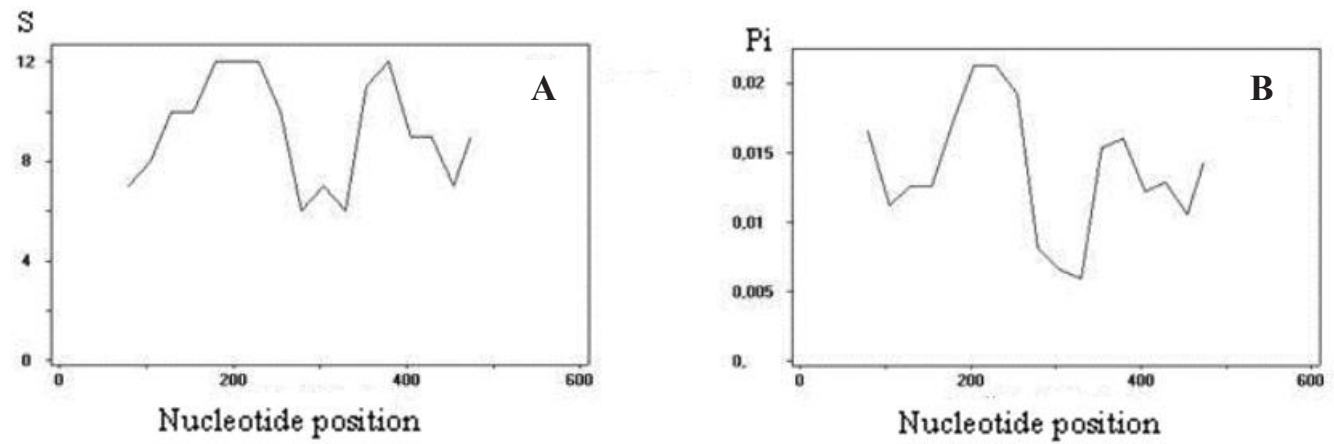

Figure 1. Base-pair sliding window of chloroplast DNA coding region for Lathyrus genus. Variability of the segregating sites (S) (A) and the nucleotide diversity (Pi) (B) for the $r b c L$ gene. 
The 29 analyzed sequences were regrouped into 25 haplotypes $(\mathrm{Hd}=0.983)$. This indicates that the Lathyrus analyzed species are evolving independently.

$\mathrm{Pi}$ values were represented on a sliding window (Figure 1B). Frequencies were balanced between 0.005-0.02. This indicates that the level of polymorphism in this gene is low. The mean nucleotide diversity value was equal to $\mathrm{Pi}=0.01449$.

The $r b c L$ gene is known to be extremely conserved among angiosperms, which is useful for phylogenetic studies of green plants (Zhang et al., 2011; Bafeel et al., 2012). However, lower mutation rates are typically observed among angiosperms in which homologies and similarities between rbcL sequences are greater than $80 \%$ (Sulaiman et al., 2003; Zhang et al., 2011).

In the Lathyrus genus, some insertions and deletions were observed that have not been reported in other species. This observation confirms the results of Asmussen and Liston (1998) who suggested that the Lathyrus genus has an elevated rate of cpDNA evolution compared to other examined genera.

\section{Phylogeny and evolution}

The sequence data were subjected to three different methods of phylogenetic reconstruction: i) UPGMA, ii) MP, and iii) maximum likelihood (ML).

Using the UPGMA method (Figure 2), the phylogenetic analyses were performed based on the evolutionary distances computed by Tajima and Nei (1984). The phylogenetic relationships established using the UPGMA dendrogram appeared to be independent from Kupicha's classification. In fact, species belonging to Lathyrus and Orobus were observed in the UPGMA dendrogram. Lathyrus belinensis, a new species, discovered by Maxted and Goyder in 1988 (http://www.lathyrus.info/species/belinensis.html), was not included in Kupicha's classification. However, this species was morphologically similar to L. odoratus (Lathyrus section). Moreover, L. tingitanus is independent from the other Lathyrus species and appears to be similar to L. clymenum. This observation is in agreement with the findings of Asmussen and Liston (1998) who examined the ropC and IR regions. The chosen out-groups (Vicia villosa, V. faba, V. sativa, and Pisum sativum) were not considered to be ancestors of the Lathyrus genus.

Using the MP method, the maximum parsimonious tree (length $=73$ steps) was obtained (Figure 3). The MP tree was obtained using the close-neighbor-interchange algorithm (Nei and Kumar, 2000) and showed a length of 0.14. MP analyses showed high consistency and retention indices $(\mathrm{CI}=0.524$ and $\mathrm{RI}=0.710)$. Moreover, composite indices were 0.516 and 0.372 for all sites and parsimony-informative sites, respectively. These values indicate a low rate of homoplasy within the sequence data and demonstrate the utility of the rbcL barcode region for identifying genetic relationships among Lathyrus species. According to the generated tree, Orobus species (except L. linifolius) were clustered together, while the Lathyrus species were opposite in the tree. The MP method confirmed the closeness of the 2 sister species L. sativus and L. cicera. Furthermore, Vicia species were clustered with Clymenum species, while Pisum were similar to the ancestor. The MP tree agreed with the reports of Asmussen and Liston (1998) regarding the closeness of Orobus, Notolathyrus, and Lathyrostylis sections.

The ML tree was constructed based on the Hasegawa-Kishino-Yano algorithm (Hasegawa et al., 1985). Otherwise the BIONJ method with an ML distance matrix draws the cladogram. The tree with the highest $\log$ likelihood score $(\operatorname{lnL}=-1190.507)$ is shown 

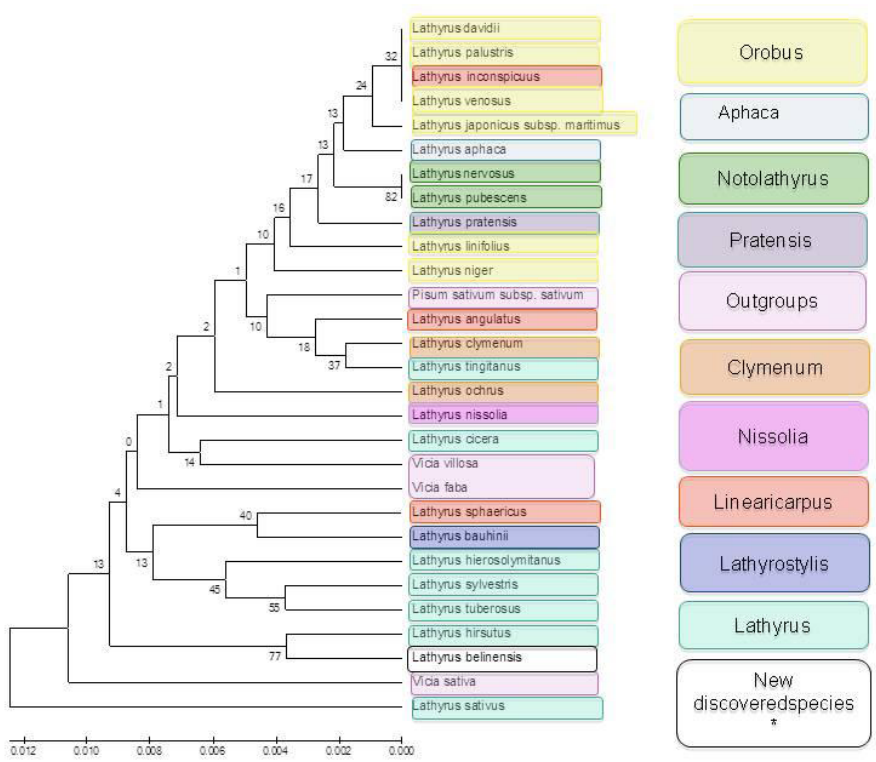

Figure 2. Unweighted pair-group method and arithmetic mean (UPGMA) dendrogram illustrating the genetic relationships between Lathyrus species based on the rbcL barcode region of the chloroplast DNA. Numbers below the nodes indicate bootstrap values.

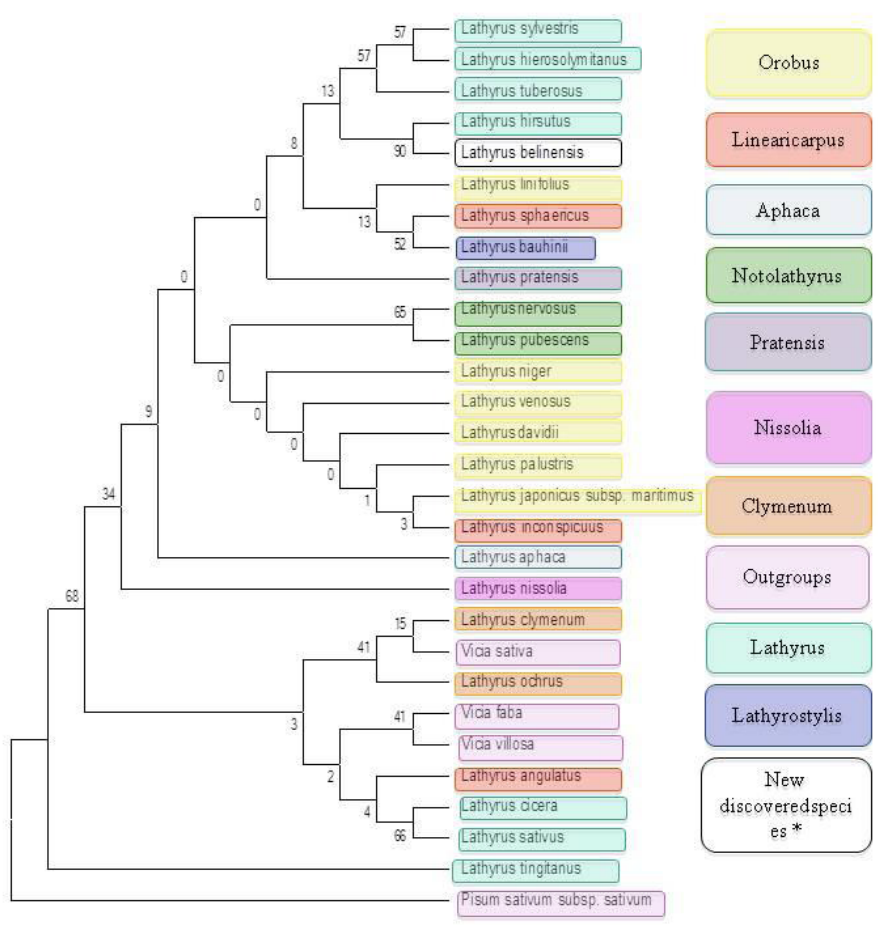

Figure 3. Strict consensus of the most highly parsimonious trees from the rbcL barcode region data set (length $=73$ steps; $\mathrm{CI}=0.524 ; \mathrm{RI}=0.710$ ). Numbers above the nodes indicate bootstrap values. 
in Figure 4. This tree was clustered into 2 main groups. The first cluster included the outgroups and Clymenum species (L. ochrus and L. clymenum) with the 3 species of Lathyrus section L. sativus, L. cicera, and L. tingitanus. On the other cluster, L. belinensis is always close to Lathyrus section species; despite its recent discovery, it appears to belong to the Lathyrus section if the Kupicha classification is considered.
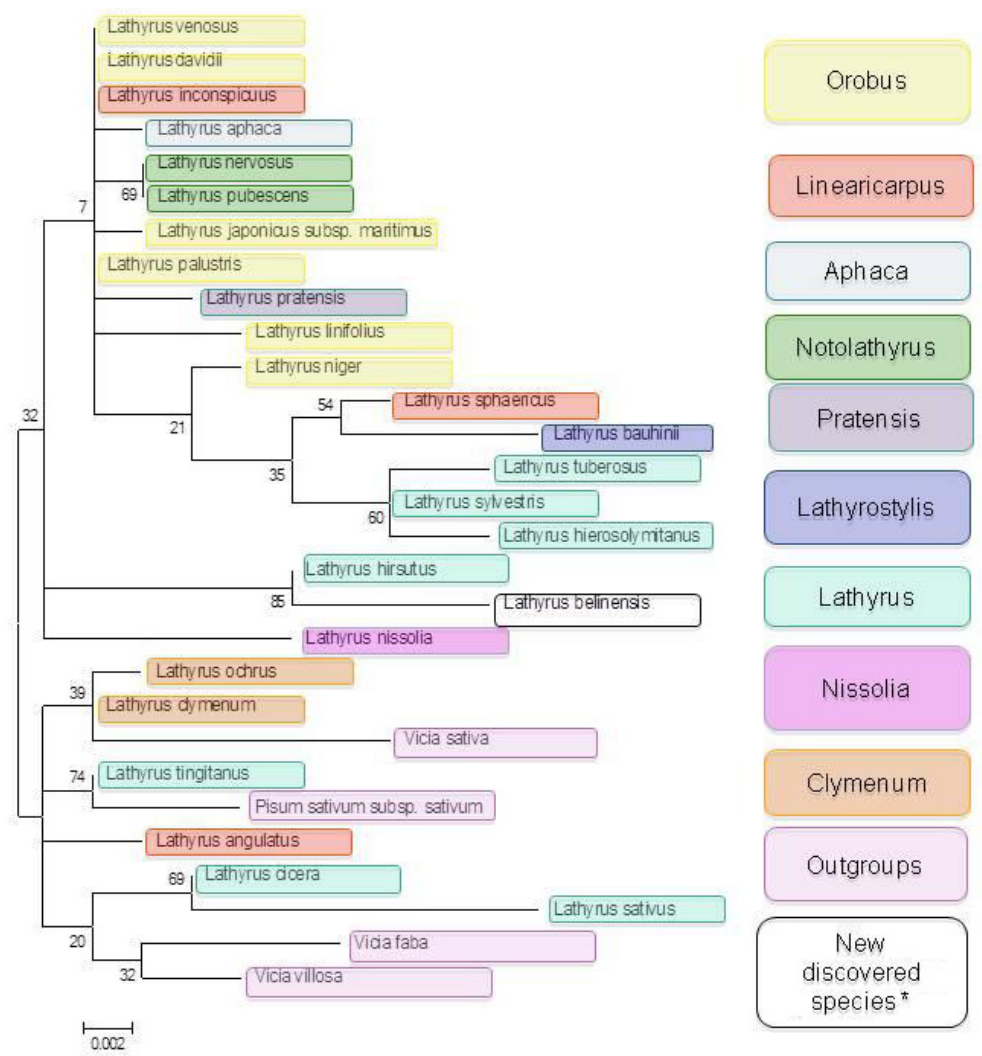

Figure 4. Maximum likelihood (ML) phylogram of the ML tree $(\operatorname{lnL}=-1190.507)$ inferred from 29 chloroplast rbcL sequences of 25 Lathyrus species and 4 other genera (3 Vicia and 1 Pisum) used as out-groups. Numbers at the nodes indicate bootstrap values.

\section{Neutral selection}

The null model in population genetics describes a scenario in which natural selection plays no role in species evolution. The test developed by Tajima (1989) was the first aimed specifically at evaluating neutrality in the context of infinite-site models of sequence evolution. Neutral selection indices of Tajima (D), Fu and Li (D and F), and Fu's (Fs) were also used to characterize the evolution of the Lathyrus genus.

As the Tajima's D index was not 0 , the neutral evolution hypothesis under no selective pressure was rejected. In the present study, the value of Tajima's D, calculated based on the 29 sequences analyzed, deviated from 0 and was negative (-1.789). This value suggests that demographic expansion or selective sweeps occurred. 
The results of Tajima's and Fu and Li's tests suggested, therefore, an excess of singletons against a low rate of intermediate variants in the entire sample. The mismatch in pairwise nucleotide differences (Figure 5) revealed a unimodal pattern that is characteristic of an expansion of the Lathyrus genus as described by Slatkin and Hudson (1991) and Rogers and Harpending (1992). These observations suggest that a demographic scenario is unlikely, as demographic processes are thought to affect all genes across all genomes (Ben Mustapha et al., 2013).

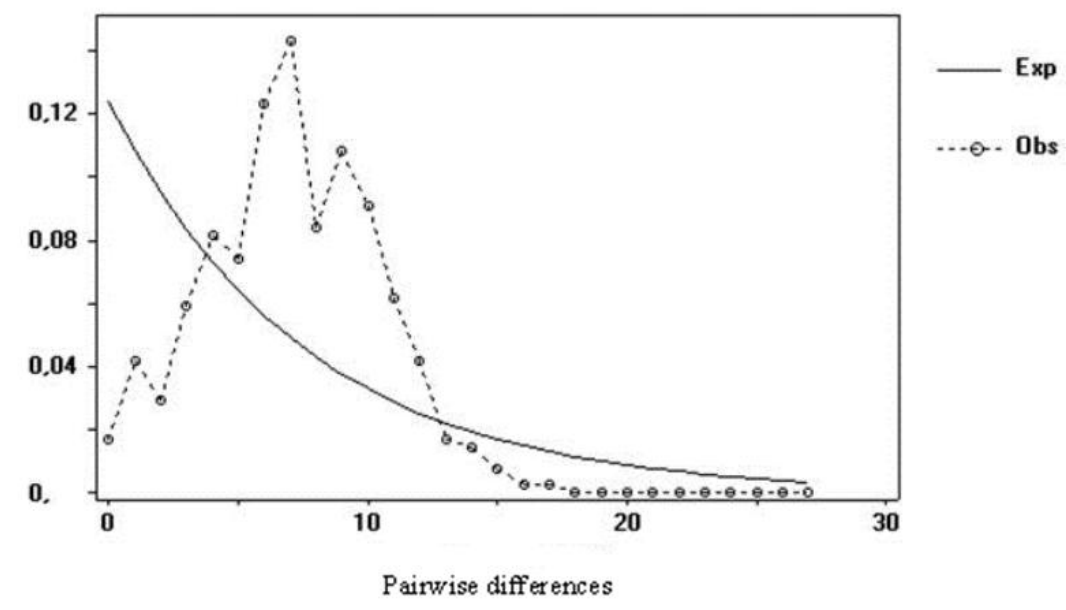

Figure 5. Mismatch distribution of the rbcL region of Lathyrus species based on pairwise nucleotide differences in the $r b c L$ gene. The solid and dashed curves indicate the expected and the observed, respectively, distributions under population expansion.

The $\mathrm{Fu}$ and $\mathrm{Li}$ indices ( $\mathrm{D}$ and $\mathrm{F}$ ) were negative but not significant ( $\mathrm{Fu}$ and $\mathrm{Li}$ 's $\mathrm{D}^{*}=$ -2.35483; Fu and Li's $\left.\mathrm{F}^{*}=-2.56018\right)$. A high negative value for Fu's was found (-16.141), indicating an excess of alleles, which is expected for recent population expansion.

Our results were consistent with balancing selective pressure in the $r b c L$ gene and demonstrate that recent population expansion occurred in the legume Lathyrus genus.

In summary, we present a robust phylogenetic hypothesis for species in the Lathyrus genus determined by analyzing the $r b c L$ gene and particularly the barcode frame of this chloroplast gene. Chloroplast DNA loci, which are thought to be uniparentally inherited and non-recombinant, have been used for systematic and phylogenetic analysis of the Lathyrus genus. The systematics of this genus remains ambiguous and is often compared with the morphological classification described by Kupicha. The $r b c L$ gene, which acts as a barcode region, was efficient for examining the phylogeny of this genus, but our results were not in $100 \%$ concordance with those of Kupicha.

\section{ACKNOWLEDGMENTS}

Research supported by grants from the Ministry of Higher Education and Scientific Research, Tunisia (Project Lab \#B02). 


\section{REFERENCES}

Albert VA (1994). Cladistic relationships of the slipper orchids (Cypripedioideae: Orchidaceae) from congruent morphological and molecular data. Lindleyana 9: 115-132.

Asmussen C and Liston A (1998). Chloroplast DNA characters, phylogeny, and classification of Lathyrus (Fabaceae). Am. J. Bot. 85: 387.

Bafeel SO, Arif IA, Bakir MA, Al Homaidan AA, et al. (2012). DNA barcoding of arid wild plants using $r b c L$ gene sequences. Genet. Mol. Res. 11: 1934-1941.

Battistin A, Biondo E and Coelho LGM (1999). Chromosomal characterization of three native and one cultivated species of Lathyrus L. in Southern Brazil. Genet. Mol. Biol. 22: 557-563.

Belaïd Y, Chtourou-Ghorbel N, Marrakchi M and Trifi-Farah N (2006). Genetic diversity within and between populations of Lathyrus genus (Fabaceae) revealed by ISSR markers. Genet. Resour. Crop Evol. 53: 1413-1418.

Ben Brahim N, Salhi A, Chtourou N, Combes D, Marrakchi M, et al. (2002). Isozymic polymorphism and phylogeny of 10 Lathyrus species. Genet. Resour. Crop Evol. 49: 427-436.

Ben Mustapha S, Ben Tamarzizt HB, Baraket G, Abdallah D (2013). A signature of balancing selection in the plastid trnL UAA intron and investigation of the genetic relationships among Tunisian plums (Prunus spp.). Sci. Hortic. 151: 51-56.

Bremer B, Andreasen K and Olsson D (1995). Subfamilial and tribal relationships in the Rubiaceae based on $r b c L$ sequence data. Ann. Missouri Bot. Gard. 82: 383-397.

Burkart A (1935). Revisión de las especies de 'Lathyrus' de la República Argentina. Rev. Fac. Agron. Vet. Univ. Buenos Aires 8: 41-128.

CBOL Plant Working Group Website (2009). Available at [http://www.barcoding.si.edu/plant_working_group.html]. Accessed September 30, 2011.

Chase MW, Salamin N, Wilkinson M, Dunwell JM, et al. (2005). Land plants and DNA barcodes: short-term and longterm goals. Phil. Trans. R. Soc. Lond. B Biol. Sci. 360: 1889-1895.

Chowdhury MA and Slinkard AE (2000). Genetics of isozymes in grasspea. J. Hered. 91: 142-145.

Chtourou-Ghorbel N, Lauga B, Combes D and Marrakchi M (2001). Comparative genetic diversity studies in the genus Lathyrus using RFLP and RAPD markers. Lathyrus Lathyrism Newslett. 2: 62-68.

Chtourou-Ghorbel N, Lauga, B, Ben Brahim N, Combes D, et al. (2002a). Genetic variation analysis in the genus Lathyrus using RAPD markers. Genet. Res. Crop. Evol. 49: 363-370.

Chtourou-Ghorbel N, Lauga B, Combes D, Ben Brahim N, et al. (2002b). Genetic diversity in selected Lathyrus species revealed by restriction fragment length polymorphism (RFLP) markers. J. Genet. Breed. 56: 279-286.

Croft AM, Pang ECK and Taylor PWJ (1999). Molecular analysis of Lathyrus sativus L. (grasspea) and related Lathyrus species. Euphytica 107: 167-176.

Dellaporta SL, Wood J and Hicks JB (1983). A plant DNA minipreparation: version II. Plant Mol. Biol. Rep. 1: 19-21.

Felsenstein J (1985). Confidence limits on phylogenies: An approach using the bootstrap. Evolution 39: 783-791.

Gouy M, Guindon S and Gascuel O (2010). SeaView version 4: A multiplatform graphical user interface for sequence alignment and phylogenetic tree building. Mol. Biol. Evol. 27: 221-224.

Hasegawa M, Kishino H and Yano T (1985). Dating of the human-ape splitting by a molecular clock of mitochondrial DNA. J. Mol. Evol. 22: 160-174.

Howe CJ, Barbrook AC, Koumandou VL, Nisbet RE, et al. (2003). Evolution of the chloroplast genome. Phil. Trans. Roy. Soc. Lond. B Biol. Sci. 358: 99-106.

ILDIS (International Legume Database and Information Service) (2002). World Database of Legumes. Version 6.05. ILDIS, Southampton.

Klamt A and Schifino-Wittmann MT (2000). Karyotype morphology and evolution in some Lathyrus (Fabaceae) species of southern Brazil. Genet. Mol. Biol. 23: 463-467.

Kress JW and Erickson DL (2007). A two-locus global DNA barcode for land plants: the coding $r b c L$ gene complements the non-coding trnH-psbA spacer region. PLoS One 6: e508.

Kupicha FK (1983). The infrageneric structure of Lathyrus. Notes R. Bot. Gard. Edinburgh 41: 209-244.

Leht M (2009). Phylogeny of old world Lathyrus L. (Fabaceae) based on morphological data. Feddes Repertorium 120: 59-74.

Levin RA, Wagner WL, Hoch PC, Nepokroeff M, et al. (2003). Family-level relationships of Onagraceae based on chloroplast $r b c L$ and $n d h F$ data. Am. J. Bot. 90: 107-115.

Maxted N and Goyder DJ (1988). A new species of Lathyrus sect. Lathyrus (Leguminosae: Papilionoideae) from Turkey. Kew Bull. 43: 711-714.

Nei M and Kumar S (2000). Molecular Evolution and Phylogenetics. Oxford University Press, New York, 128.

Genetics and Molecular Research 13 (4): 8729-8739 (2014)

CFUNPEC-RP www.funpecrp.com.br 
Olmstead RG and Reeves PA (1995). Evidence for the polyphyly of the Scrophulariaceae based on chloroplast $r b c L$ and $n d h F$ sequences. Ann. Missouri Bot. Gard. 82: 176-193.

Rogers AR and Harpending H (1992). Population growth makes waves in the distribution of pairwise genetic differences. Mol. Biol. Evol. 9: 552-569.

Rozas J (2009). DNA Sequence Polymorphism Analysis Using DnaSP. In: Bioinformatics for DNA Sequence Analysis. Methods in Molecular Biology Series (Posada D, ed.). Humana Press, New York, 337-350.

Simola LK (1986). Structural and Chemical Aspects of Evolution of Lathyrus Species. In: Lathyrus and Lathyrism (Kaul AK and Combes D, eds.). Third World Medical Research Foundation, New York, 225-239.

Slatkin M and Hudson RR (1991). Pairwise comparisons of mitochondrial DNA sequences in stable and exponentially growing populations. Genetics 129: 555-562.

Sulaiman SF, Culham A and Harborne JB (2003). Molecular phylogeny of Fabaceae based on $r b c L$ sequence data: with special emphasis on the tribe Mimoseae (Mimosoideae). Asia Pac. J. Mol. Biol. Biotechnol. 11: 9-35.

Tajima F (1989). Statistical method for testing the neutral mutation hypothesis by DNA polymorphism. Genetics 123: 585-595.

Tajima F and Nei M (1984). Estimation of evolutionary distance between nucleotide sequences. Mol. Biol. Evol. 1: 269-285.

Tamura K, Peterson D, Peterson N, Stecher G, et al. (2011). MEGA5: molecular evolutionary genetics analysis using maximum likelihood, evolutionary distance, and maximum parsimony methods. Mol. Biol. Evol. 28: 2731-2739.

Yukawa T and Uehara K (1996). Vegetative diversification and radiation in subtribe Dendrobiinae (Orchidaceae): evidence from chloroplast DNA phylogeny and anatomical characters. Plant Syst. Evol. 201: 1-14.

Zhang B, Luo L, Zhang X, Li R, et al. (2011). Bioinformatics analysis on ribulose-1,5-bisphosphate carboxylase/oxygenase large subunits in different plants. Mol. Plant Breed. 2: 101-108. 